\title{
Risk Factors of Birth Asphyxia : Literature Review
}

\author{
Aprilia Irma Damayanti ${ }^{\mathrm{a}}$, Mahendra Tri Arif Sampurna ${ }^{\mathrm{b}}$, Aditiawarman $^{\mathrm{c}}$ \\ ${ }^{\text {a }}$ Student of Midwivery Study Program, Faculty of Medicine, Airlangga University \\ ${ }^{\mathrm{b}}$ Depatment of Pediatrics, Faculty of Medicine, Airlangga University \\ cDepartment of KSM Obstetric and Gynecology, Faculty of Medicine, Airlangga University
}

\begin{abstract}
Background: Birth asphyxia is a condition of failure to start breathing in neonates or unable to maintain spontaneous breathing at birth. Neonatal asphyxia is a contributor to 30-35\% of neonatal deaths. The incidence of birth asphyxia in infants in developing countries is 10 times greater than in developed countries, especially if maternal and neonatal health ${ }^{\text {services }}$ are inadequate. The incidence of asphyxia is inseparable from the accompanying risk factors. Therefore, this study aims to determine the risk factors for the incidence of asphyxia in newborns based on fetal and maternal factors. Method: This research is a literature review where researchers will review articles that are relevant to predetermined criteria. Articles were screened based on titles, abstracts, keywords, inclusion criteria, and the contents of the entire text, and the seven most relevant articles were obtained for review. Result: The results of a literature search showed that the most risk factors for the incidence of birth asphyxia were: Fetal factors consisting of low birth weight, prematurity, meconium amniotic fluid, malpresentation, and umbilical cord entanglement. Then on maternal factors, the most risk factors were prolonged labor, preeclampsia, primigravida mothers, and post-term pregnancies. Conclussion : Based on the results of a search of seven literature, researchers have taken the most mentioned factors and grouped these factors into 2 factors, namely fetal factors and maternal factors.
\end{abstract}

Keywords : Birth Asphyxia, Risk Factors

\section{Introduction}

Globally, in 2020 WHO stated that infant mortality reached 2.4 million in the first month of life. Every day, there are an estimated 6700 neonatal deaths. However, there has been rapid progress in efforts to reduce neonatal mortality, from 5 million deaths in 1990 to 2.4 million in 2019 . According to WHO 2019 data, Indonesia ranks 7 out of 10 countries with the highest newborn mortality rates. in the world [17]. The infant mortality rate can be used as an indicator in assessing the health and welfare of society. The Neonatal Mortality Rate according to the latest data in 2019 showed that Indonesia reached 12.41/1000 live births [16]. The most common causes of neonatal death in 2017 were premature birth, then intrapartum complications (birth asphyxia or respiratory failure in neonates), and infection [17].

Birth asphyxia is a condition of failure to start breathing in neonates or unable to maintain spontaneous breaths at birth. Neonatal asphyxia is a contributor to 30-35\% of neonatal deaths[1]. About $10 \%$ of newborns fail to initiate their first breath. As many as 3-5\% of them require basic resuscitation from medical personnel, and $<1 \%$ require advanced resuscitation[2]. Asphyxia is defined as disruption 
of the process of blood circulation and oxygen exchange during the prenatal (placenta) phase to the postnatal (lung) phase during and immediately after the birth of the baby. This condition causes vital organs to experience hypoxia. Many factors are related to asphyxia, starting from fetal, placental, and maternal factors [18].

The incidence of birth asphyxia in infants in developing countries is 10 times greater than in developed countries, especially if maternal and neonatal health services are inadequate [18]. According to Mukhtar (2018), the incidence of asphyxia is a contributor to around 800,000 perinatal deaths every year. Nigeria, which is a country with the highest infant mortality rate in Africa. As many as $33 \%$ of newborn deaths in Nigeria are caused by birth asphyxia[3]. According to research by Yadav \& Danke (2017), it is stated that $23 \%$ of neonatal deaths in developing and lower-middle-class countries are caused by asphyxia. Asphyxia is the 5th biggest cause of infant and under-five mortality after pneumonia, diarrhea, infection, and complications of prematurity[2]. In Indonesia alone, the number of neonatal deaths due to asphyxia cases reached 11,133.89 deaths in 2019 [16]. Birth asphyxia becomes a worrying condition if it is not treated immediately because it contributes to the morbidity and mortality of newborns[2].

Based on many studies, there are many risk factors associated with the incidence of asphyxia. According to research at Nisthar Hospital Multan in 2020, they grouped the results of research on asphyxia risk factors into 3 things, namely maternal factors as much as $30 \%$ consisting of hypertension, oligohydramnios, polyhydramnios, diabetes, PROM, and UTI. Then there is the placental factor of $47.3 \%$ consisting of placental insufficiency and placental abruption). The third factor is the $22.7 \%$ fetal factor, namely fetal distress, IUGR, MAS, and malpresentation. To assess the condition of neonatal asphyxia, an evaluation can be carried out every 1.5, and 10 minutes using the APGAR score [4]. According to a study by Acharya (2020), the incidence of birth asphyxia was more commonly found in vaginal deliveries than in cesarean sections. $47.8 \%$ of infants had mild and $52.2 \%$ of moderate degrees of asphyxia. Asphyxia should be prevented by integrated ANC and active management during labor[5].

Research conducted at an independent practice of Palembang midwives in 2019 showed that there was a significant relationship $(\mathrm{p}<0.005)$ on several variables with infant asphyxia, namely maternal age at risk, prematurity, and breech position. Meanwhile, there is no statistically significant relationship between prolonged labor and the incidence of asphyxia, but mothers who experience prolonged labor have a 2.28-fold greater chance of asphyxia (Khoiriah \& Pratiwi, 2019). Research by Ardyana (2019) also describes factors that are significantly related to the incidence of asphyxia, namely umbilical cord entanglement, prolonged labor, and placenta previa [7].

The understanding of health workers regarding risk factors for birth asphyxia is considered very important in promotive and preventive efforts for pregnant women. This study aims to determine the risk factors for asphyxia in newborns based on fetal and maternal factors. 


\section{Method}

This research is a literature review where researchers will review articles that are relevant to predetermined criteria. Articles were obtained from searches through Google Scholar, Pubmed, and Science direct by filtering the criteria for the 2017-2021 article year. The inclusion criteria set were articles of the last 5 years, full-text access, in Indonesian or English, there was a match between the objectives and results of the research, and was primary research, not a literature review, systematic review, or meta-analysis. The keywords used in the article search were birth asphyxia risk factor, neonatal asphyxia. The first search found 88 articles from 57 Google Scholar articles, 18 from Pubmed, and 13 from Science Direct. The articles were then screened based on the title, abstract, keywords, and inclusion criteria so that 15 articles were found that were deemed relevant to be re-screened. The second screening is based on the content of the entire text and obtained the 7 most relevant articles for review.

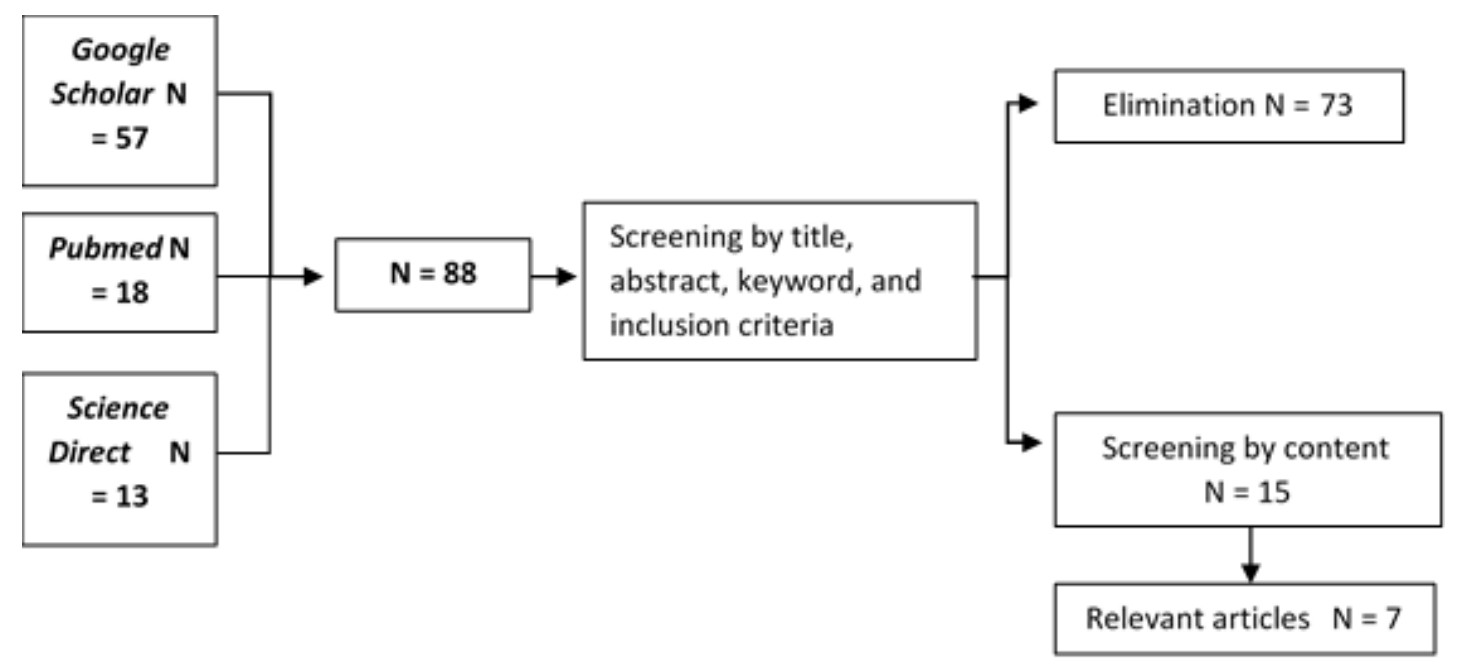

Fig 1. Screening Method Diagram 
Table 1. Article Summary Results

\begin{tabular}{|c|c|c|c|c|c|}
\hline No & Research Title & Author & Purpose & Method & \\
\hline 1 & $\begin{array}{l}\text { Birth Asphyxia and } \\
\text { Associated Factors } \\
\text { Among Newborns } \\
\text { Delivered in Jimma } \\
\text { Zone Public } \\
\text { Hospitals, } \\
\text { Southwest Ethiopia: } \\
\text { A Cross-Sectional } \\
\text { Study }\end{array}$ & $\begin{array}{l}\text { Zelalem Jebessa } \\
\text { Wayessa, Tefera } \\
\text { Belachew, } \\
\text { Jophin Joseph. }\end{array}$ & $\begin{array}{l}\text { Knowing } \\
\text { asphyxia in } \\
\text { newborns and } \\
\text { related factors in } \\
\text { public hospitals, } \\
\text { Southwest } \\
\text { Ethiopia. }\end{array}$ & $\begin{array}{l}\text { A cross-sectional } \\
\text { study was } \\
\text { conducted on } 368 \\
\text { live newborns }\end{array}$ & $\begin{array}{l}\text { The prevalenc } \\
\text { newborn ba } \\
\text { Significantly r } \\
\text { prolonged labo } \\
\text { meconium, tigl } \\
\text { routine ANC, m }\end{array}$ \\
\hline 2 & $\begin{array}{l}\text { Description of Risk } \\
\text { Factors in Asphyxia } \\
\text { Neonatorum Cases } \\
\text { at RSIA Budi } \\
\text { Kemuliaan Jakarta }\end{array}$ & $\begin{array}{l}\text { Rahmatullah } \\
\text { Razak }\end{array}$ & $\begin{array}{l}\text { Knowing the } \\
\text { description of } \\
\text { the factors that } \\
\text { cause the } \\
\text { incidence of } \\
\text { asphyxia in } \\
\text { neonates }\end{array}$ & $\begin{array}{l}\text { Case-control with } \\
360 \text { samples }\end{array}$ & $\begin{array}{l}\text { The frequency } \\
\text { asphyxia cases } \\
\text { the baby facto } \\
\text { malpresentation } \\
\text { the baby. } \\
\text { factors consis } \\
\text { history of di } \\
\text { certain conditi } \\
\text { such as PROM } \\
\text { labor induction. }\end{array}$ \\
\hline 3 & $\begin{array}{l}\text { Low Birth, } \\
\text { Prematurity, and } \\
\text { Pre-Eclampsia as } \\
\text { Risk Factors of } \\
\text { Neonatal Asphyxia }\end{array}$ & $\begin{array}{l}\text { Remita Yuli } \\
\text { Kusumaningrum, } \\
\text { Bhisma Murt, } \\
\text { Hanung Prasetya }\end{array}$ & $\begin{array}{l}\text { Exploring risk } \\
\text { factors for } \\
\text { asphyxia in } \\
\text { neonates at } \\
\text { Nganjuk } \\
\text { Hospital, East } \\
\text { Java. }\end{array}$ & $\begin{array}{l}\text { Analytical } \\
\text { observational } \\
\text { study with a case- } \\
\text { control design. } \\
\text { The total sample } \\
\text { is } 150 \text { neonates. }\end{array}$ & $\begin{array}{l}\text { Low birth } \\
\text { preeclampsia } \\
\text { premature birth } \\
\text { shown to contr } \\
\text { risk of birth asp }\end{array}$ \\
\hline 4 & $\begin{array}{l}\text { Risk Factors of } \\
\text { Perinatal Asphyxia } \\
\text { Among Newborns } \\
\text { Delivered at Public } \\
\text { Hospitals in Addis } \\
\text { Ababa, Ethiopia: } \\
\text { Case-Control Study }\end{array}$ & $\begin{array}{l}\text { Tewodros } \\
\text { Mulugeta, Girum } \\
\text { Sebsibe, } \\
\text { Fikirtemariam } \\
\text { Abebe Fenta, } \\
\text { Migbar Sibhat }\end{array}$ & $\begin{array}{l}\text { Assess risk } \\
\text { factors for } \\
\text { perinatal } \\
\text { asphyxia }\end{array}$ & $\begin{array}{l}\text { An unmatched } \\
\text { case-control study } \\
\text { was conducted on } \\
213 \text { subjects }\end{array}$ & $\begin{array}{l}\text { Several factors } \\
\text { related to the } \mathrm{i} \\
\text { asphyxia are } \\
\text { fetal distress, } \\
\text { device-induced } \\
\text { low birth } \\
\text { hemorrhage. }\end{array}$ \\
\hline 5 & $\begin{array}{l}\text { Risk Factors of } \\
\text { Birth Asphyxia }\end{array}$ & $\begin{array}{l}\text { Yodit Zewdie } \\
\text { Berhe, Abel }\end{array}$ & $\begin{array}{l}\text { determine risk } \\
\text { factors for }\end{array}$ & $\begin{array}{l}\text { Case-control with } \\
390 \text { samples }\end{array}$ & $\begin{array}{l}\text { Multivariate } \\
\text { tendency for }\end{array}$ \\
\hline
\end{tabular}




\begin{tabular}{|c|c|c|c|c|c|}
\hline & $\begin{array}{l}\text { Among Neonates } \\
\text { Born in Public } \\
\text { Hospitals of Tigray, } \\
\text { Northern Ethiopia }\end{array}$ & $\begin{array}{l}\text { Gidey Kebedom, } \\
\text { Letekikrstos } \\
\text { Gebregziabher, } \\
\text { et al. }\end{array}$ & $\begin{array}{l}\text { neonatal } \\
\text { asphyxia at } \\
\text { public hospitals } \\
\text { of Tigray, } \\
\text { Ethiopia. }\end{array}$ & & $\begin{array}{l}\text { occur in infant } \\
\text { entanglement, } \\
\text { membranes, } \\
\text { maternal cor } \\
\text { primipara, post } \\
\text { preeclampsia. }\end{array}$ \\
\hline 6 & $\begin{array}{l}\text { Prevalence and } \\
\text { contributing factors } \\
\text { of birth asphyxia } \\
\text { among the neonates } \\
\text { delivered at Nigist } \\
\text { Eleni Mohammed } \\
\text { memorial teaching } \\
\text { hospital, Southern } \\
\text { Ethiopia: a cross- } \\
\text { sectional study }\end{array}$ & $\begin{array}{l}\text { Ritbano Ahmed } \\
\text { Abdo, Hassen } \\
\text { Mosa Halil, } \\
\text { Biruk Assefa } \\
\text { Kebede, Abebe } \\
\text { Alemu Anshebo } \\
\text { and Negeso } \\
\text { Gebeyehu Gejo }\end{array}$ & $\begin{array}{l}\text { Assessing the } \\
\text { incidence of } \\
\text { newborn } \\
\text { asphyxia and the } \\
\text { accompanying } \\
\text { risk factors }\end{array}$ & $\begin{array}{l}\text { cross-sectional } \\
\text { study was carried } \\
\text { out on } 279 \\
\text { participants }\end{array}$ & $\begin{array}{l}\text { There are as } \\
\text { newborns who } \\
\text { condition of } \\
\text { membranes, ti } \\
\text { prematurity, p } \\
\text { also primiparo } \\
\text { the risk of asphy }\end{array}$ \\
\hline 7 & $\begin{array}{l}\text { Birthweight is an } \\
\text { independent } \\
\text { predictor of birth } \\
\text { asphyxia in twins: } \\
\text { A retrospective } \\
\text { cross-sectional } \\
\text { cohort study of } \\
5337 \text { Chinese twins }\end{array}$ & $\begin{array}{l}\text { Hong Cui, Ziwei } \\
\text { Wang, Jinzhe } \\
\text { Yu, Caixia Liu, } \\
\text { CGTBFA }\end{array}$ & $\begin{array}{l}\text { Identify the } \\
\text { incidence of } \\
\text { newborn twins } \\
\text { who have } \\
\text { asphyxia and } \\
\text { determine the } \\
\text { weight } \\
\text { percentile of } \\
\text { babies who have } \\
\text { asphyxia. }\end{array}$ & $\begin{array}{l}\text { Secondary data } \\
\text { analysis. } \\
\text { Retrieved } \\
\text { sociodemographic } \\
\text { and obstetric data } \\
\text { from the } \\
\text { electronic records } \\
\text { systems. }\end{array}$ & $\begin{array}{l}\text { The incidence } \\
\text { asphyxia was } \\
\text { which } 9.35 \% \mathrm{~h} \\
\text { and } 4.16 \% \mathrm{~h} \\
\text { Twins born at } \mathrm{r} \\
\text { are those with } \\
(64.8 \%) \text {. Mea } \\
\text { normal weight a }\end{array}$ \\
\hline
\end{tabular}




\section{DISCUSSION}

Based on the search results, we have found 7 most relevant articles for review. The discussion section will describe risk factors for birth asphyxia based on 7 selected articles which are narrated in the following paragraphs :

\section{- FETAL FACTORS :}

\section{a. Low Birth Weight}

The results of a study conducted at the Nganjuk hospital, East Java, Indonesia in 2019 by Kusumaningrum et al, found that babies born with low birth weight had a statistically significant relationship with the incidence of neonatal asphyxia $(\mathrm{p}<0.05)$. LBW babies have a 2.58 times greater risk of asphyxia than babies who are not LBW. The instability of the body's condition at birth makes the system in the body more susceptible to problems, these conditions have an impact on morbidity and even mortality in infants.[8]. The results of the same study by Wayessa, et al (2018) stated that the chance of asphyxia increased by 4.2 times higher in LBW infants. Babies with low birth weight are associated with the incidence of prematurity which causes the baby's lungs to not fully mature and the ability of the respiratory muscles to function is limited. This is associated with a high risk of neonatal asphyxia[9].

A study in China by Cui et al (2021) stated that they found $13.5 \%$ of twins born with asphyxia where LBW was a significant predictor. The results showed that the number of asphyxia twins reached $64.8 \%$ in twins born weighing $<1500$ grams from the total sample, while twins with ideal body weight had a very low asphyxia rate of $3.6 \%$. Increased asphyxia occurs as the baby loses weight at birth[10]. Razak (2021) stated that babies born with low birth weight did not receive adequate support from the placenta. This makes them deficient in glucose, carbohydrates, and oxygen supply which causes problems including unstable breathing function at birth, this can be seen from the low APGAR score. Their research descriptively describes the majority of asphyxia babies (38.3\%) born with low body weight when compared to asphyxia babies who have ideal birth weight with a percentage of $12.5 \%$ [11].

\section{b. Prematurity}

The results of research by Abdo (2019), premature birth is one of the contributors to neonatal mortality by $21.8 \%$ in Ethiopia in 2015. Premature birth is also associated with perinatal asphyxia, where the results of their study found that babies born prematurely had a higher probability of being born prematurely. nearly 5 times the risk of asphyxia at birth. This is caused by insufficient pulmonary surfactant in infants aged <37 weeks. Surfactants play an important role in keeping the alveolar surface elastic, avoiding excessive tension, and maintaining the stability of the alveolus function. Insufficient surfactant production in premature babies causes asphyxia syndrome when the baby is born[12]. Not only that, The Indonesian Pediatrician Association (IDAI) explained that premature babies are very susceptible to hypothermia and asphyxia due to the lack of oxygen supply to newborns. Riskesdas 2007 data describes asphyxia as a risk factor for asphyxia, namely $37 \%$, then premature (34\%) and the third is sepsis (12\%) (IDAI, 2014).

The results of the same study were stated by Kusumaningrum (2019) that asphyxia is closely related to the condition of fetal prematurity, where babies born prematurely have a 1.27 times greater chance of birth asphyxia. The results of their multivariate analysis obtained a p-value $<0.05$, which means that premature was significantly associated with asphyxia statistically. This is due to immature or immature lungs, so breathing problems can occur at birth[8]. Not only that, Tewodros Mulugeta (2020) stated that premature birth is a risk factor that causes birth asphyxia. They stated that the risk of asphyxia increased 3.4 times in infants born prematurely than infants born at term gestational age. Preventing a premature birth is one of the efforts to reduce neonatal mortality. Premature birth is often associated with 
conditions of low birth weight which will cause various disorders for the fetus in early life, including asphyxia problems. Premature babies tend to have insufficient surfactant production to maximize respiratory function, so they are very susceptible to asphyxia[13].

\section{c. Meconium Amniotic Fluid}

According to Ahmed (2020) stated the results of his research that meconium was a risk factor for increasing the incidence of asphyxia 29.2 times higher when compared to clear membranes. The rationale for the incidence of asphyxia in infants who have cloudy amniotic fluid is that meconium can cause inflamed lung tissue, narrowing of the airways, and pulmonary air leaks if there is inhalation and aspiration of meconium fluid by the baby at birth. This will lead to the output of hypoxia and asphyxia of neonates[14]. Asphyxia is 7.5 times more likely to occur in infants with meconium amniotic fluid at birth. This is because aspiration of meconium fluid disrupts fetal lung surfactant synthesis and surfactant is deactivated. This incident causes the newborn to have difficulty breathing spontaneously which is called asphyxia[12].

The results of a similar study by Wayessa (2018) stated that meconium amniotic fluid mixed with blood was an 8.29-fold risk factor for causing birth asphyxia compared to clear membranes. Aspiration of meconium fluid causes airway obstruction that ends in asphyxia. Babies born with cloudy amniotic fluid are very susceptible to asphyxia so it is necessary to prepare for rapid and appropriate resuscitation management. Prevention of severe asphyxia can be done by medical personnel by endotracheal meconium suctioning immediately when the baby is born[9].

The results of the same study to support the studies above were also obtained from a study at Addis Ababa Hospital, Ethiopia in 2020 that the increased risk of asphyxia was 9.02 times higher in infants born with meconium membranes. Several studies in various countries are also in line with this research. Cloudy amniotic fluid or meconium causes the majority of airway obstruction in newborns and lung inflammation leading to neonatal asphyxia[13].

\section{d. Malpresentation}

Non-cephalic presentations such as breech or transverse increase the risk of birth asphyxia by 6.98 times when compared with the normal fetal position. Cord prolapse and trauma are the results of some malpresentation of the fetus, mainly the breech position. A pinched umbilical cord due to prolapse will increase the risk of asphyxia[9]. The results of a similar study were also obtained by Ahmed (2020) that fetuses with a non-vertex presentation had a 5.49-fold risk of birth asphyxia compared to babies born with a back of the head presentation. Just like previous studies, they also linked the condition of malpresentation with umbilical cord prolapse which has a chance of a lack of oxygen supply due to pinching of the umbilical cord[14].

\section{e. Tight umbilical cord}

According to Ahmed (2020), tight umbilical cord entanglement has a significant relationship with birth asphyxia. The umbilical cord entanglement increases the risk of birth asphyxia by 5.67 times compared to other normal babies. The umbilical cord plays an important role in the supply of blood, oxygen, and nutrients from the mother to the fetus. The function of the umbilical cord is disturbed due to the coiling and pinched umbilical cord resulting in its function is not optimal so that the fetus is at risk of lack of oxygen, especially if it is accompanied by clogged arteries and veins of the fetal neck due to tight entanglement of the umbilical cord[14]

A higher increase in the risk of asphyxia due to a very tight umbilical cord was found in Wayessa's (2018) study, which is 7.4 times. Babies with tightly wrapped umbilical cords are 7.4 times more likely to have birth asphyxia. Oxygen exchange is not smooth and inadequate blood supply due to entanglement of the umbilical cord can cause breathing problems at birth or called asphyxia[9]. The 
results of the same study by Abdo (2019) also found that a tightly wrapped umbilical cord increased the risk of asphyxia by 3.1 times. The twist of the umbilical cord here has the meaning of a $360^{\circ}$ circle around the neck of the fetus. This causes restriction of blood circulation in the neck of the fetus due to tight pressure on the umbilical cord. In addition, the exchange of blood rich in oxygen and nutrients is not smooth, so it is very susceptible to birth asphyxia[12].

\section{- MATERNAL FACTORS :}

\section{a. Prolonged Labor}

The second stage of labor more than 3 hours increases the risk of asphyxia in newborns 3.72 . The condition of prolonged labor is closely related to fetal distress due to exhaustion from the mother and also the fetus. The immediate intervention will be able to help reduce the incidence of birth asphyxia[9]. The results of the same study by Abdo (2019) also stated that prolonged labor was significantly associated with the incidence of birth asphyxia. Mothers who experience prolonged labor in the second stage have a 4.6 times chance to give birth to an asphyxiated baby. This is associated with stress on the fetus due to too long the labor process[12]. According to Ardyana (2019), childbirth is one of the important factors that contribute to asphyxia. A long labor process is 3 times more likely to produce an asphyxiated baby. The impact of asphyxia cannot be ignored, it can give output in the form of morbidities such as mental retardation, neurological disorders, circulatory failure, and even infant mortality[7].

\section{b. Preeclampsia}

According to Kusumaningrum (2019), preeclampsia is one of the predisposing factors for the incidence of birth asphyxia. This condition causes placental insufficiency which results in hypoxia during and after the baby is born. Preeclampsia increases the risk of birth asphyxia by 3.74 times compared to mothers who do not have preeclampsia. The results of their study revealed a statistically significant effect between preeclampsia and birth asphyxia. In preeclampsia, the balance of vasodilator and vasoconstrictor hormones tends to be disturbed. This causes the blood to be sent to the placenta will be reduced so that oxygen is also reduced which results in fetal hypoxia. The prognosis of fetal hypoxia if not immediately treated will be severe neonatal asphyxia. According to Indah (2016) in Kusumaningrum (2020) states the condition of preeclampsia is when there is an increase in blood pressure which results in disrupted blood flow to the placenta unlike normal conditions so that oxygen and nutrients are reduced to the fetus due to disturbances in the placenta. Preeclampsia is associated with endothelial dysfunction[8].

The results of the same study were also obtained from that preeclampsia is a form of obstetric complications. Mothers with obstetric complications are 3.76 times more likely to have asphyxia in their babies at birth[9]. Not only that, but Ahmed (2020) also stated the results of his research that hypertensive mothers who lead to preeclampsia have a 12.4-fold greater chance of having their babies experience birth asphyxia. Of course, this condition is very worrying because intrauterine fetal growth will be disrupted due to a lack of nutrition and blood supply from the placenta[14].

\section{c. Primigravida mothers}

Primigravida mothers were significantly associated with the incidence of birth asphyxia. According to Abdo (2019), the chance of a primigravida mother to give birth to an asphyxia baby is 5.1 times greater than that of a multigravida mother. Primigravida is often associated with non-progressive labor which leads to fetal stress and respiratory distress[12]. The results of the same study were obtained by Ahmd (2020) that primigravida was one of the risk factors for asphyxia in newborns. Primigravida 
mothers have a 5.5 times greater risk of asphyxia when the baby is born. This is related to primiparous mothers who may not have enough knowledge and experience about their pregnancy so that they sometimes do not get regular ANC services.[14]. In Wayessa's research (2018), it is also stated that mothers who do not perform routine ANC care are at risk of 4.6 times for asphyxia in their babies at birth. Mothers with complete and integrated antenatal care can monitor the condition and welfare of the fetus so that if complications occur, they can be resolved immediately[9].

\section{d. Post-term Pregnancy}

The results showed that post-term pregnancies had a 2.73 times greater chance of asphyxia in their babies at birth. This condition is the result of the inability of the placenta to provide adequate blood, oxygen, and nutrition supplies due to an overdue gestational age. The placenta will work optimally at < 37 weeks of gestation, after which its function will begin to decline. The longer the gestational age, the needs of the fetus from the placenta cannot be adequately met. This causes various clinical manifestations, one of which is birth asphyxia[14].

Batubara and Fauziyah (2020) stated the results of their research that post-term or postdate pregnancy was significantly associated with asphyxia. Post-term pregnancy is gestational age $>42$ weeks or more calculated starting from the first day of the last menstrual period. Postdate mothers are 5.83 times more likely to have asphyxia in their fetuses at birth. Postdate pregnancy is often associated with fetal distress due to a lack of blood supply and nutrition(Coal \& Fauziah, 2020).

\section{CONCLUSSION}

Based on the results of a search of seven literature, several risk factors related to birth asphyxia were obtained. Researchers have taken the most mentioned factors and grouped these factors into 2 factors, namely fetal factors consisting of low birth weight, prematurity, amniotic fluid meconium, malpresentation, and umbilical cord entanglement. Then the second on maternal factors, the highest risk factors were prolonged labor, preeclampsia, primigravida mothers, and post-term pregnancies. The understanding of health workers regarding risk factors for birth asphyxia is considered very important in promotive and preventive efforts.

\section{References}

[1] R. Moshiro, P. Mdoe, and J. M. Perlman, "A Global View of Neonatal Asphyxia and Resuscitation," Front. Pediatr., vol. 7, no. November, pp. 1-6, 2019, doi: 10.3389/fped.2019.00489.

[2] N. Yadav and S. Damke, "Study of risk factors in children with birth asphyxia," Int. J. Contemp. Pediatr., vol. 4, no. 2, p. 518, 2017, doi: 10.18203/2349-3291.ijcp20170701.

[3] M. Mukhtar-Yola, L. I. Audu, O. Olaniyan, H. T. Akinbi, A. Dawodu, and E. F. Donovan, "Decreasing birth asphyxia: Utility of statistical process control in a low-resource setting," BMJ Open Qual., vol. 7, no. 3, 2018, doi: 10.1136/bmjoq-2017-000231.

[4] M. F. Mehar et al., "Risk factors of perinatal asphyxia at Nishtar Hospital Multan.," Prof. Med. J., vol. 27, no. 03, pp. 487-492, 2020, doi: 10.29309/tpmj/2020.27.03.3176.

[5] A. Acharya et al., "Clinico-Biochemical Correlation in Birth Asphyxia and Its Effects on Outcome," Cureus, vol. 12, no. 11, 2020, doi: 10.7759/cureus.11407.

[6] A. Khoiriah and T. Pratiwi, "Faktor-Faktor Yang Berpengaruh Terhadap Kejadian Asfiksia Pada Bayi Baru Lahir,” J. 'Aisyiyah Med., vol. 4, no. 2, 2019, doi: 10.36729/jam.v4i2.218. 
[7] D. Ardyana and E. P. Sari, "Hubungan Lilitan Tali Pusat, Partus Lama Dan Plasenta Previa Dengan Kejadian Asfiksia Neonatorum," J. 'Aisyiyah Med., vol. 4, no. 3, pp. 364-374, 2019, doi: 10.36729/jam.v4i3.209.

[8] R. Y. Kusumaningrum, B. Murti, and H. Prasetya, "Low Birth, Prematurity, and Pre-Eclampsia as Risk Factors of Neonatal Asphyxia,” J. Matern. Child Heal., vol. 04, no. 01, pp. 49-54, 2019, doi: 10.26911/thejmch.2019.04.01.07.

[9] Z. J. Wayessa, T. Belachew, and J. Joseph, "Birth asphyxia and associated factors among newborns delivered in Jimma zone public hospitals, Southwest Ethiopia: A cross-sectional study.," J. Midwifery Reprod. Heal., vol. 6, no. 2, pp. 1289-1295, 2018, doi: 10.22038/JMRH.2018.10483.

[10] H. Cui, Z. Wang, J. Yu, and C. Liu, "Birthweight is an independent predictor of birth asphyxia in twins: A retrospective cross-sectional cohort study of 5337 Chinese twins," Eur. J. Obstet. Gynecol. Reprod. Biol., vol. 257, pp. 106-113, 2021, doi: 10.1016/j.ejogrb.2020.12.014.

[11] R. Razak, "Gambaran faktor risiko pada kasus asfiksia neonatorum di RSIA Budi Kemuliaan Jakarta,” J. Kesehat. Masy., vol. 11, no. 01, pp. 58-63, 2021.

[12] R. A. Abdo, H. M. Halil, B. A. Kebede, A. A. Anshebo, and N. G. Gejo, "Prevalence and contributing factors of birth asphyxia among the neonates delivered at Nigist Eleni Mohammed memorial teaching hospital, Southern Ethiopia: A cross-sectional study," BMC Pregnancy Childbirth, vol. 19, no. 1, pp. 1-7, 2019, doi: 10.1186/s12884-019-2696-6.

[13] M. T., S. G., F. F.A., and S. M., "Risk factors of perinatal asphyxia among newborns delivered at public hospitals in addis ababa, Ethiopia: Case-control study," Pediatr. Heal. Med. Ther., vol. 11, pp. 297-306, 2020, [Online]. Available: https://www.dovepress.com/getfile.php?fileID=61023.

[14] S. Ahmed, "Risk Factors of Birth Asphyxia Among Neonates Born in Public Hospitals of Tigray , Northern," 2020.

[15] A. R. Batubara and N. Fauziah, "Faktor Yang Memengaruhi Kejadian Asfiksia Neonatorum Di Rsu Sakinah Lhokseumawe Factors Influencing The Incidence Of Asphyxia Neonatorum At Sakinah Hospital In Lhokseumawe,” J. Healthc. Technol. Med., vol. 6, no. 1, pp. 411-423, 2020.

[16] World Health Organization. "Maternal, Newborn, Child and Adolescent Health and Ageing", 2020 [online] https://platform.who.int/data/maternal-newborn-child-adolescent-ageing/maternal-andnewborn-data

[17] World Health Organization, "Newbrns : Improving Survival and Well-Being", 2020 [online] https://www.who.int/news-room/fact-sheets/detail/newborns-reducing-mortality

[18] Gillam-Krakauer M, Gowen Jr CW, "Birth Asphyxia. In: StatPearls. StatPearls Publishing, Treasure Island" (FL); 2020. PMID: 28613533, 2017.

[19] https://www.sdg2030indonesia.org

[20] Kaban RK. "One of the Handling of Premature Babies that Needs to be Known. Indonesian Pediatrician Association". [online] https://www.idai.or.id/artikel/seputar-kesehatan-anak/salah-satupenanganan-bayi-prematur-yang-perlu-diketahui 